\title{
Sickle Cell-Hemoglobin C Disease
}

National Cancer Institute

\section{Source}

National Cancer Institute. Sickle Cell-Hemoglobin C Disease. NCI Thesaurus. Code C34676.

A hemoglobinopathy that is considered a hybrid of sickle cell disease and hemoglobin C disease. Patients present with the symptoms of sickle cell disease but the latter are less frequent and severe compared to sickle cell disease. 